\title{
Adrenomedullin in the growth modulation and differentiation of acute myeloid leukemia cells
}

\author{
ROSA DI LIDDO ${ }^{1}$, DEBORAH BRIDI ${ }^{1}$, MICHELE GOTTARDI $^{2}$, SERGIO DE ANGELI ${ }^{3}$, \\ CLAUDIO GRANDI $^{1}$, ALESSIA TASSO ${ }^{1}$, THOMAS BERTALOT ${ }^{1}$, GIOVANNI MARTINELLI $^{4}$, \\ FILIPPO GHERLINZONI $^{2}$ and MARIA TERESA CONCONI ${ }^{1}$
}

\begin{abstract}
${ }^{1}$ Department of Pharmaceutical and Pharmacological Sciences, University of Padova, Padova; ${ }^{2}$ Department of Haematology, General Hospital, Treviso; ${ }^{3}$ Treviso Cord Blood Bank and Hematopoietic Cell Culture Laboratory, Transfusional Center, General Hospital, Treviso; ${ }^{4}$ Institute of Haematology 'L. and A. Seràgnoli', Department of Experimental, Diagnostic and Specialty Medicine, 'S. Orsola-Malpighi' University Hospital, University of Bologna, Bologna, Italy
\end{abstract}

Received October 30, 2015; Accepted January 11, 2016

DOI: 10.3892/ijo.2016.3370

\begin{abstract}
Adrenomedullin (ADM) is a regulatory peptide endowed with multiple biological effects, including the regulation of blood pressure, cell growth and innate host defence. In the present study, we demonstrated that ADM signaling could be involved in the impaired cellular differentiation of myeloid leukemia cells to mature granulocytes or monocytes by modulating RAMPs/CRLR expression, PI3K/Akt cascade and the ERK/MAPK signaling pathway. When exogenously administered to in vitro cultures of HL60 promyelocytic leukemia cells, ADM was shown to exert a strong proliferative effect with minimal upregulation in the expression level of monocyte antigen CD14. Notably, the experimental inhibition of ADM signaling with inhibitor $\mathrm{ADM}_{22-52}$ promoted a differentiative stimulation towards monocytic and granulocytic lineages. Moreover, based on the expression of CD31 relative to CD38, we hypothesized that an excess of ADM in bone marrow (BM) niche could increase the transendothelial migration of leukemia cells while any inhibitory event of ADM activity could raise cell retention in hyaluronate matrix by upregulating CD38. Taken into consideration the above evidence, we concluded that ADM and $\mathrm{ADM}_{22-52}$ could differently affect the growth of leukemia cells by autocrine/paracrine mechanisms and may have clinical relevance as biological targets for the intervention of tumor progression.
\end{abstract}

Correspondence to: Professor Rosa Di Liddo, Department of Pharmaceutical and Pharmacological Sciences, University of Padova, Via Marzolo 5, I-35131, Padova, Italy

E-mail: rosa.diliddo@unipd.it

Key words: adrenomedullin, $\mathrm{ADM}_{22-52}$, HL60 cells, acute myeloid leukemia

\section{Introduction}

Acute myeloid leukemias are a heterogeneous group of clonal neoplastic diseases due to genetic and epigenetic alterations of hematopoietic stem cells (HSCs) or committed progenitors, causing an aberrant growth of myeloid precursor cells.

Acute promyelocytic leukemia (APL), a subtype of AML, is characterized by an abnormal accumulation of promyelocytes following specific translocation $\mathrm{t}(15 ; 17)(\mathrm{q} 21 ; 12)$ and formation of promyelocytic leukemia (PML)/retinoic acid receptor $\alpha(\mathrm{RAR} \alpha)$ fusion gene. It has been demonstrated that the PML-RAR $\alpha$ fusion protein is involved in the pathogenesis of APL through the recruitment of a complex that, composed of nuclear co-repressor molecule (NCOR) and histone deacetylase (HDAC), inhibits the expression of myeloid differentiation genes (1). Under treatment with all-trans-retinoic acid (ATRA), the NCOR/HDAC complex is dissociated from RAR and the maturation of promyelocytes is restored. Standard protocols combining ATRA with anthracycline-based chemotherapy are demonstrated to guarantee $\sim 70 \%$ cure rate (2).

Originally isolated from human pheochromocytoma, adrenomedullin is a 52 aa peptide belonging to the calcitonin gene-related peptide family (3). Its maturation involves the proteolytic cleavage of preproadrenomedullin, a precursor of 185 amino acid residues that includes at amino terminal end the so-called proadrenomedullin $\mathrm{N}$-terminal 20 peptide (PAMP), a peptide with known transient hypotensive activity $(4,5)$.

The biological effects of ADM are mainly mediated by its interaction with two cell-surface receptors, multimeric complexes of calcitonin receptor-like receptor (CRLR) and receptor-activity-modifying proteins (RAMPs). It is known that the RAMP family includes three members (RAMP1, RAMP2 and RAMP3) and regulates both transport and ligand specificity of CRLR. When RAMP2 or RAMP3 is associated with CRLR, adrenomedullin receptors 1 (AMR1) and 2 (AMR2) are generated, respectively, while RAMP1 is included in calcitonin gene-related peptide (CGRP) receptors $(6,7)$.

Although ADM was first described as a potent vasodilator and hypotensive factor, several studies reported that it exerts 
Table I. Antibodies used for flow cytometric analysis.

Antibodies

Manufacturing company

Primary antibodies

FITC rat anti-human CD11b

FITC mouse anti-human CD11c

PE mouse anti-human CD14

PE mouse anti-human CD31

FITC mouse anti-human CD33

FITC mouse anti-human CD34

Mouse anti-human CD38

PE mouse anti-human CD45

PE mouse anti-human cKIT

PE mouse anti-human HLA DR

FITC mouse anti-human Lineage cocktail 1 (CD3, CD14, CD16, CD19, CD20, CD56)

Goat anti-human ADM

Rabbit anti-human RAMP1

Rabbit anti-human RAMP2

Rabbit anti-human RAMP3

Goat anti-human CRLR

Rabbit anti-human Akt

Rabbit anti-human p(Ser473)-Akt

Rabbit anti-human p44/42 MAPK

Rabbit anti-human phosho (Thr202/Tyr204)-p44/42 MAPK

Secondary antibodies

PE goat anti-mouse

PE donkey anti-goat

Alexa Fluor 488 goat anti-rabbit

Isotype controls

$\mathrm{PE}$ isotype control

FITC isotype control
BD Biosciences

BD Biosciences

Santa Cruz Biotecnology

Dako

BD Biosciences

BD Biosciences

Santa Cruz Biotecnology

Santa Cruz Biotecnology

Santa Cruz Biotecnology

Santa Cruz Biotecnology

BD Biosciences

Santa Cruz Biotecnology

Santa Cruz Biotecnology

Santa Cruz Biotecnology

Santa Cruz Biotecnology

Santa Cruz Biotecnology

Santa Cruz Biotecnology

Santa Cruz Biotecnology

Cell Signaling Technology

Cell Signaling Technology

Santa Cruz Biotecnology

Santa Cruz Biotecnology

Invitrogen-Life Technologies

Santa Cruz Biotecnology

BD Biosciences various biological activities acting in an autocrine/paracrine manner (8). ADM is produced and secreted by several cell types, such as neurons, epithelial and endothelial cells supporting their survival and/or proliferation (9). Compelling evidence has shown that adrenomedullin can contribute to the pathogenesis of solid tumors in several ways (10). Firstly, the hypoxic conditions induce an upregulation of the peptide in the tumor cells leading to stimulation of cell growth and inhibition of apoptosis (11). Secondly, ADM exerts proangiogenic effects thus providing nutrients and oxygen to the tumor and allowing the spreading of tumor cells (12). Thirdly, it decreases the expression of proinflammatory cytokines, thus, inhibiting the immune system (13).

ADM is involved in the regulation of hematopoietic compartment as demonstrated by its expression in peripheral blood granulocytes, lymphocytes, monocytes and monocyte-derived macrophages under homeostatic and lipopolysaccharide-induced inflammation (14-16). Notably, ADM stimulates the proliferation of human cord blood hematopoietic stem cells through autocrine mechanism $(17,18)$.

Based on the above evidence and considering that ADM plays a critical role in cancer cell proliferation, the aim of the present study was to evaluate whether ADM signaling is involved in the maintenance of impaired differentiation of APL cells to mature granulocytes or monocytes. Thus, the proliferative and differentiative effects induced by ADM and its inhibitor, $\mathrm{ADM}_{22-52}$, were evaluated in vitro at different time-points in HL60 cells, a human promyelocytic leukaemia cell line widely used to study granulocyte differentiation (19).

\section{Materials and methods}

Cell culture. Human promyelocytic leukaemia cell line HL60 (kindly provided by CRO, Aviano, Italy) was grown in Iscove's medium (Sigma-Aldrich, St. Louis, MO, USA) supplemented with $10 \%$ fetal bovine serum (FBS; Sigma-Aldrich) and 1\% antibiotic antimycotic solution (Sigma-Aldrich) at $37^{\circ} \mathrm{C}$ in a humidified atmosphere containing $5 \% \mathrm{CO}_{2}$.

Flow cytometry (FCM). The expression level of endogenous ADM ( ADM $\left._{\text {endo }}\right)$, RAMP1, RAMP2, RAMP3 and CRLR was studied in HL60 cells cultured under resting or primed conditions with exogenous ADM $\left(\mathrm{ADM}_{\text {exo }}\right)$ and $\mathrm{ADM}_{22-52}$. After washing with $0.5 \% \mathrm{BSA}$ in PBS, the samples were 
Table II. Primer sequences used for RT-PCR and qPCR analysis.

Target

Sequence $\left(5^{\prime}-3^{\prime}\right)$

Length

Peptidylglycine $\alpha$-amidating monooxygenase (PAM)

F-GCGCAAGCACTTTGATATGCCTCA

R-TCTGCAATTCTGAGGAGGTGGGTT NM_000919.3

220

Cullin 5 (Cul5)

F-GAACCAAAGACCCAGAGAGAAA

NM_003478.3

81

R-GTCCTCCTAAGTTCAGCATCAG

Glyceraldehydes 3-phosphate dehydrogenase (GAPDH)

F-AGGTCGGAGTCAACGGATTTGGT

R-ACAAAGTGGTCGTTGAGGGCAATG NM_002046.3

910

Hypoxanthine-guanine phosphoribosyltransferase (HPRT) F-ATGGACAGGACTGAACGTCTTGCT

R-TGAGCACACAGAGGGCTACAATG NM_000194.2

F, forward; R, reverse.

incubated with primary antibodies (Table I) for $15 \mathrm{~min}$ at room temperature (RT). For indirect staining, the detection of specific binding sites was carried out by staining for $15 \mathrm{~min}$ at RT with Alexa Fluor ${ }^{\circledR} 488$ - or PE-conjugated secondary antibodies. For intracellular staining, HL60 cells were prefixed with BD Cytofix/Cytoperm solution (BD Biosciences, San Josè, CA, USA) for 20 min at $4^{\circ} \mathrm{C}$. Data were analyzed by FACSCanto II flow cytometer (BD Biosciences) and expressed as percentage $(\%) \pm$ standard deviation $(\mathrm{SD})$ of positive cells compared with II antibody (Ab)- or isotype-matched controls. Statistical significance was calculated by Student's t-test.

Gene expression study of PAM. Total mRNA of HL60 cells was isolated using TRIzol ${ }^{\circledR}$ reagent (Sigma-Aldrich), according to the manufacturer's protocol. From each sample, $1 \mu \mathrm{g}$ total RNA was reverse transcribed into cDNA by using M-MLV reverse transcriptase (Sigma-Aldrich), and oligo (dT) ${ }_{23}$ primers (Invitrogen-Life Technologies, Paisley, UK). The amplification reaction was performed by PTC-100 thermal cycler (Bio-Rad Laboratories, Hercules, CA, USA) using ReadyMix ${ }^{\mathrm{TM}}$ Taq PCR Reaction Mix with $\mathrm{MgCl}_{2}$ (SigmaAldrich), primer pairs designed to detect peptidylglycine $\alpha$-amidating monooxygenase (PAM) and housekeeping gene GAPDH (Table II). PCR products were electrophoresed on $2 \%$ agarose gel (Sigma-Aldrich) pre-stained with GelRed ${ }^{\mathrm{TM}}$, and then visualized by UV transilluminator Gel Doc $2000 \mathrm{Gel}$ Documentation system (Bio-Rad Laboratories).

ADM secretion assay. The constant release of endogenous ADM into culture medium was studied in HL60 cells using protein transport inhibition. Cells were seeded at density of $1 \times 10^{5}$ cells $/ \mathrm{ml}$ and then cultured for 12,36 and $60 \mathrm{~h}$ in proliferation medium before incubation for $12 \mathrm{~h}$ at $37^{\circ} \mathrm{C}$ with GolgiPlug ${ }^{\mathrm{TM}}$ (BD Biosciences). At 24, 48 and $72 \mathrm{~h}$ after plating, the samples were collected and then submitted to permeabilization with BD Cytofix/Cytoperm solution. The analysis was performed by intracellular ADM staining followed by flow cytometric analysis, as above reported. In the present study, cultures untreated with GolgiPlug ${ }^{\mathrm{TM}}$ were used as positive control of ADM secretion. The acquired data were analyzed by the overton substraction tool of Summit 4.3 software
(Beckman Coulter, Inc., Brea, CA, USA) and were reported as percentage $(\%) \pm \mathrm{SD}$ of ADM positive cells compared with relative II Ab-matched control.

Treatment of HL60 cells with exogenous ADM and ADM 22-52. Cells were seeded in $25-\mathrm{cm}^{2}$ flasks at a density of $1 \times 10^{5}$ cells $/ \mathrm{ml}$ and then cultured for $72 \mathrm{~h}$ with different concentrations of $\mathrm{ADM}$ (ranging from $0.625 \times 10^{-8} \mathrm{M}$ to $5 \times 10^{-8} \mathrm{M}$ ) (SigmaAldrich) or $5 \times 10^{-7} \mathrm{M} \mathrm{ADM}_{22-52}$ (Sigma-Aldrich) $(13,18,20)$. In parallel, untreated cultures were used as reference. At the end of the treatment, growth assay and FCM analysis of endogenous ADM system were carried out. In parallel, cytospin preparations for May-Grunwald Giemsa staining were made to detect morphological changes of the nuclei.

Growth assay. At $72 \mathrm{~h}$, cell suspensions were collected and then centrifuged at $1,200 \mathrm{rpm}$ for $5 \mathrm{~min}$ at $4^{\circ} \mathrm{C}$. After resuspension of pellets in $1 \mathrm{ml}$ of Iscove's medium, HL60 cells were counted by Nexcelom Bioscience-Auto T4 Cellometer (Invitrogen-Life Technologies). Data are expressed as mean of total cell number \pm SD of three independent experiments performed in triplicate. Statistical analysis was performed using the Student's t-test.

Investigation of PI3K/Akt and MAPK/ERK signaling pathways. At different time-points $(5,15$ and $30 \mathrm{~min})$ after stimulation, the activation of PI3K/Akt and MAPK/ERK signaling pathways was evaluated in HL60 cells treated with $5 \times 10^{-8} \mathrm{M}$ $\mathrm{ADM}$ and $5 \times 10^{-7} \mathrm{M} \mathrm{ADM}_{22-52}$. The analysis was performed by FCM as previously described, using antibodies specific for phosphorylated and unphosphorylated forms of Akt and MAPK enzymes (Table I). In parallel, untreated samples were used as reference. For each marker and its corresponding II Ab-matched control, data were reported as geometric mean fluorescence intensity (MFI) \pm SD. Statistical significance was calculated using the Student's t-test comparing primed cells with resting samples.

Differentiative response of $H L 60$ cells to $A D M_{\text {exo }}$ and $A D M_{22-52}$ Quantitative real-time polymerase chain reaction ( $q P C R)$. The quantitative analysis of Cullin 5 (Cul5) gene expres- 


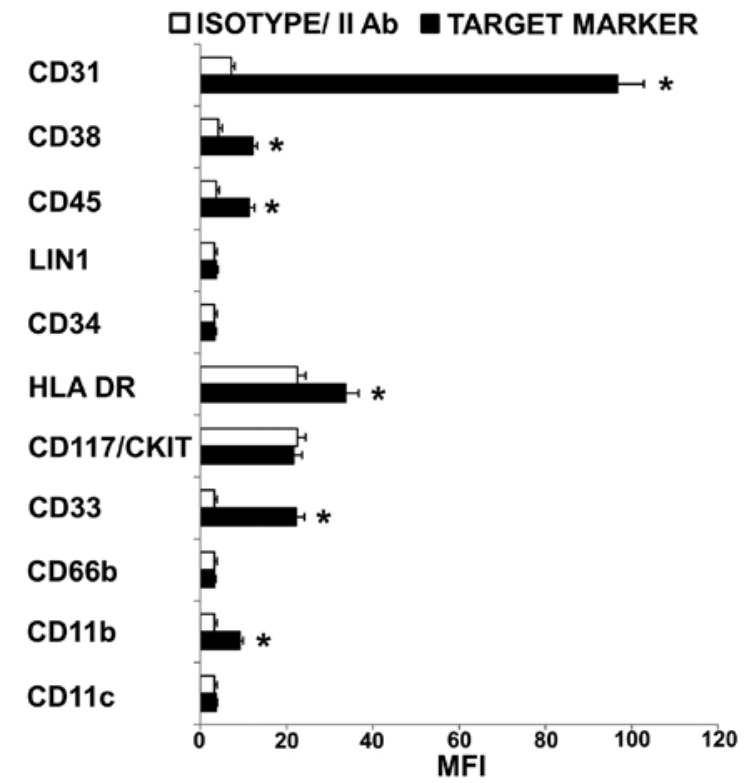

Figure 1. Characterization by flow cytometry of HL60 cells. Data were expressed as mean fluorescence intensity (MFI) $\pm \mathrm{SD}$. White bars, isotypeor secondary (II) Ab-matched control; black bars, target marker-matched samples.

sion was performed using Platinum ${ }^{\circledR}$ SYBR $^{\circledR}$ Green qPCR SuperMix-UDG (Invitrogen-Life Technologies) and oligo primers (Invitrogen-Life Technologies) designed for the detection of Cul5 and hypoxanthine-guanine phosphoribosyltransferase (HPRT) housekeeping gene (Table II). The amplification reactions were performed using a DNA Engine
Opticon Real-Time Thermal Cycler (Bio-Rad Laboratories). The relative expression of Cul5 mRNA was determined using the $\Delta \Delta \mathrm{C}_{\mathrm{T}}$ Livak method (21) and data were reported as fold increase calculated using the $2^{-\Delta \Delta C T} \pm \mathrm{SD}$ equation.

$F C M$. At $72 \mathrm{~h}$ after stimulation with $\mathrm{ADM}_{\text {exo }}$ and $\mathrm{ADM}_{22-52}$, the samples were collected and then analysed by flow cytometry to measure the expression of myeloid differentiation markers and adhesion molecules (CD45, CD34, CD66b, CD11b, CD11c, CD14, CD31 and CD38). The samples were prepared as described above using antibodies listed in Table I. For each marker, data were expressed as the ratio of geometric MFI $(\mathrm{rMFI}) \pm \mathrm{SD}$ derived from primed cells and relative resting samples. Statistical significance was calculated using the Student's t-test.

Histochemistry. Air-dried slides of cells were prepared using a Cytospin 4 (Thermo Fisher Scientific, Inc., Waltham, MA, USA) at $500 \mathrm{rpm}$ for $5 \mathrm{~min}$. The slides were fixed in methanol (SigmaAldrich) for $5 \mathrm{~min}$ and then stained for $5 \mathrm{~min}$ in $50 \%(\mathrm{v} / \mathrm{v})$ May-Grunwald stain (Merck Millipore, Billerica, MA, USA) followed by $15 \mathrm{~min}$ in $10 \%$ Giemsa stain (Merck Millipore). Both stain solutions were freshly made using Sorenson's phosphate buffer (133 mM, pH 6.6). After staining, the slides were washed and destained for $5 \mathrm{~min}$ in the phosphate buffer.

\section{Results and Discussion}

Immunophenotype of HL60 cells. Before priming with $\mathrm{ADM}_{\text {exo }}$ and $\mathrm{ADM}_{22-52}$, the immunophenotype of HL60 cells was explored by FCM evaluating the expression level
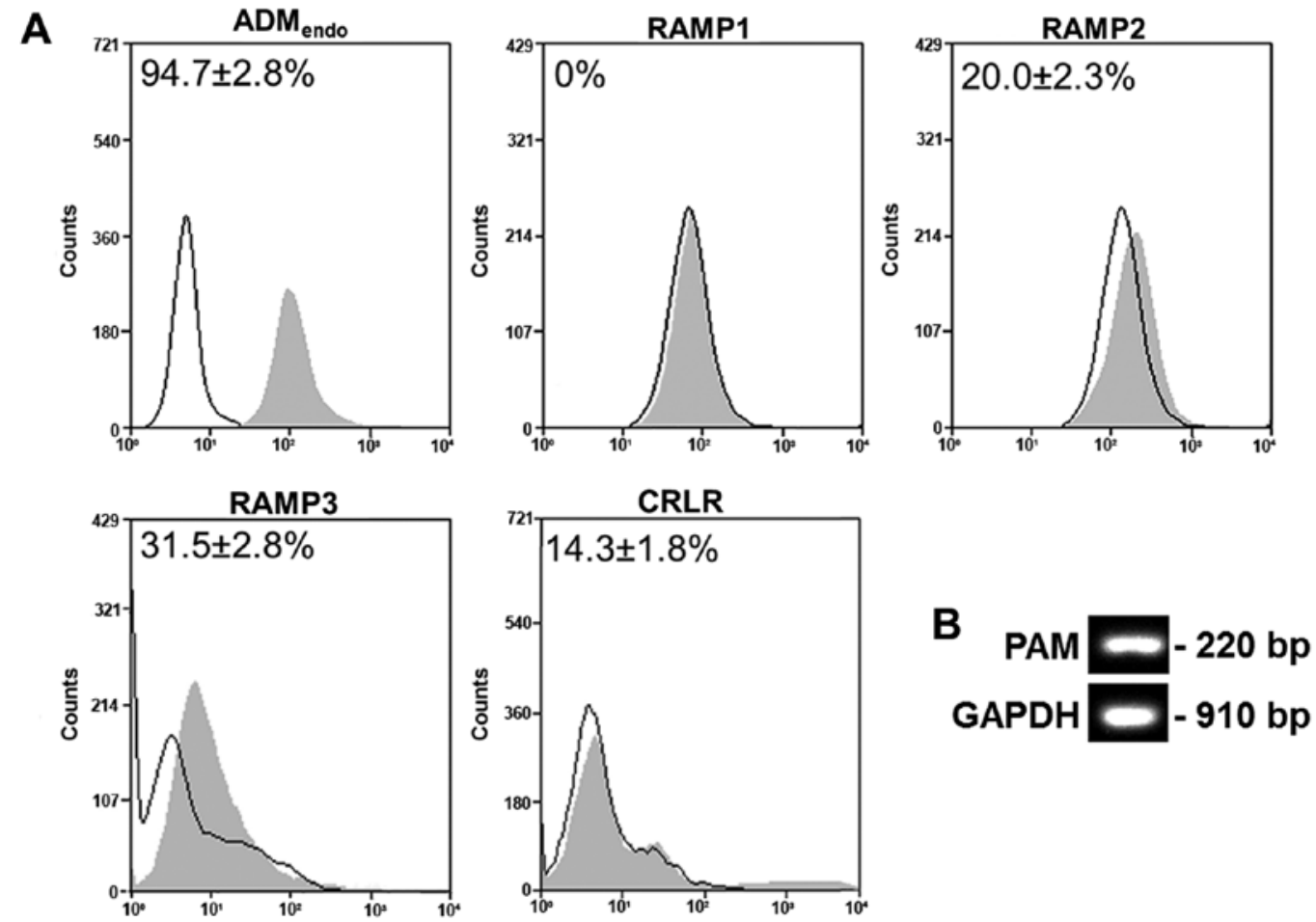

Figure 2. (A) The immunophenotypic analysis was performed by FCM to detect the expression of endogenous ADM (ADM endo $_{\text {) }}$ ADM receptors (RAMP1/2/3, CRLR) using specific primary antibodies and Alexa Fluor 488- and PE-conjugated secondary antibody. In parallel, secondary antibody-matched controls were used as reference. For each marker, the percentage (\%) \pm SD of positive cells (grey peak) was detected by the substraction statistical tool of Summit 4.3 software using as reference II Ab-matched control (black peak). (B) Analysis by RT-PCR of PAM gene in HL60 cells cultured at basal conditions. In parallel, the expression of GAPDH housekeeping gene was considered. The amplification products were electrophoresed on $2 \%$ agarose gel and stained by GelRed ${ }^{\mathrm{TM}}$. 

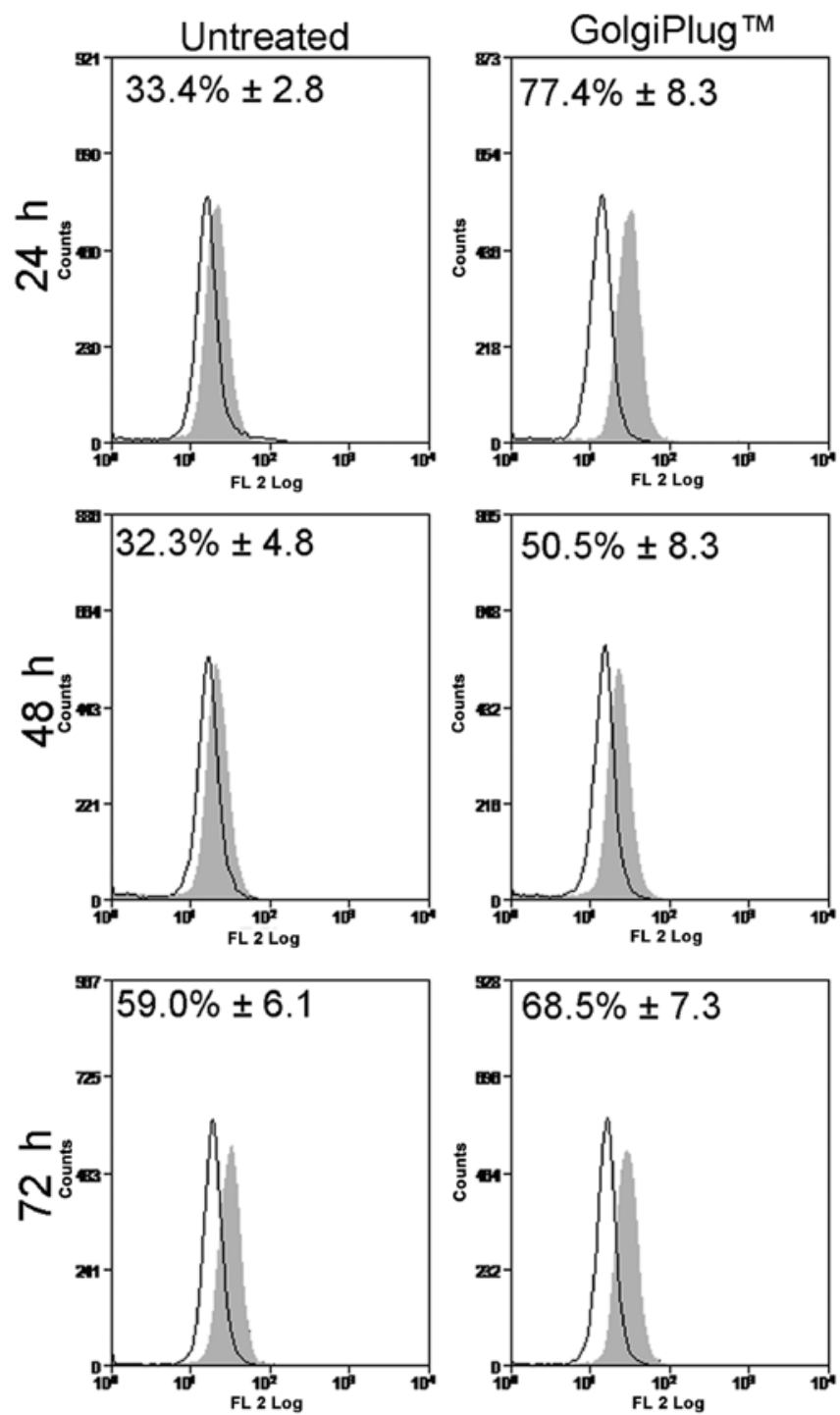

Figure 3. ADM secretion in HL60 cells was demonstrated using protein transport inhibition. Cells were cultured for 12,36 and $60 \mathrm{~h}$ in proliferation medium before incubation for $12 \mathrm{~h}$ with Brefeldin A/GolgiPlug ${ }^{\mathrm{TM}}$. Thus, the samples were collected at 24,48 and $72 \mathrm{~h}$ from plating and analyzed by intracellular ADM staining followed by flow cytometric analysis. In this analysis, cultures untreated with GolgiPlug ${ }^{\mathrm{TM}}$ were used as positive control of ADM secretion. The acquired data were expressed as a percentage $(\%) \pm \mathrm{SD}$ of ADM positive cells (grey filled peak) compared to II Ab-matched control (black profile).

of undifferentiated and differentiated state markers (Fig. 1). The myeloid phenotype was confirmed by the expression of CD33 while the presence of stem cell compartment was suggested by the absent expression of CD117/CKIT, Lin 1 and CD34 (22,23). Moreover, the undifferentiated state of cells was demonstrated by the negative or low fluorescence intensity of HLA-DR, CD45, CD11b, CD11c and CD66b (24-27). Among adhesion molecules expressed by acute myelogenous leukemia blasts, CD31 $(28,29)$ and CD38 (30) are reported to play pivotal role in the interaction of tumor cells with microenviromental elements, i.e. CD31 on the surface of marrow endothelial cells (CD31/CD31 and CD38/CD31 interactions) and hyaluronate (CD38/hyaluronate interactions). In the present study, an excess of CD31 relative to CD38 was detected (CD31/CD38 MFI ratio >1) suggesting that HL60 cells have a high potential

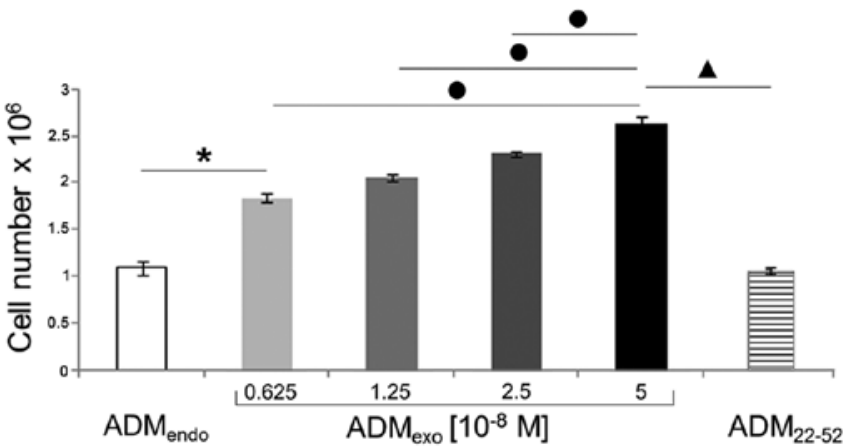

Figure 4. Proliferative effect of exogenous ADM solutions (from $0.625 \times 10^{-8} \mathrm{M}$ to $5 \times 10^{-8} \mathrm{M}$ ) and $5 \times 10^{-7} \mathrm{M} \mathrm{ADM}_{22-52}$ on HL60 cells cultured for $72 \mathrm{~h}$ Untreated cultures $\left(\mathrm{ADM}_{\text {endo }}\right)$ were used as reference. Bars are means $\pm \mathrm{SD}$ $(\mathrm{n}=10)$. ${ }^{*} \mathrm{P}<0.05$ using the Student's t-test. ${ }^{*} \mathrm{P}<0.05$ vs. $\mathrm{ADM}_{\text {endo }}$ reference group; ${ }^{\bullet} \mathrm{P}<0.05$ and ${ }^{\wedge} \mathrm{P}<0.05$ vs. $5 \times 10^{-8} \mathrm{M} \mathrm{ADM}_{\text {exo }}$.

of transendothelial migration (31-33). Similar expression level of CD31, CD33, CD38 in HL60 and APL cells was considered important to define a prospective correlation between in vitro and in vivo conditions.

HL60 cells express ADM and its receptors. As reported in Fig. 2A, HL60 cells were shown to express $\mathrm{ADM}_{\text {endo }}$ $(94.7 \pm 2.8 \%)$, RAMP2 $(20.0 \pm 2.3 \%)$, RAMP3 $(31.5 \pm 2.8 \%)$ and CRLR $(14.3 \pm 1.8 \%)$. In contrast, RAMP1 was not detected. The gene expression of peptidylglycine $\alpha$-amidating monooxygenase (PAM), that is the enzyme producing $\alpha$-amidated bioactive peptide from the inactive precursor (34), confirmed the potential of cells to synthesize the active form of ADM (Fig. 2B). Produced by peripheral blood mononuclear and polymorphonuclear cells, ADM is known to regulate cell growth or differentiation through an autocrine mode of action (15). As shown in Fig. 3, the release of ADM endogenously synthetized by HL60 cells was evaluated using Brefeldin A/ GolgiPlug $^{\mathrm{TM}}$ kit, a protein transport inhibitor that is able to prevent the secretion process and to trap peptides into intracellular compartments. The increased immunoreactivity for ADM in GolgiPlug ${ }^{\mathrm{TM}}$-treated samples $(24 \mathrm{~h}, 77.4 \pm 8.3 \%$; $48 \mathrm{~h}$, $50.5 \pm 8.3 \%$; and $72 \mathrm{~h}, 68.5 \pm 7.3 \%$ ) compared to untreated cells ( $24 \mathrm{~h}, 33.4 \pm 2.8 \%$; $48 \mathrm{~h}, 32.3 \pm 4.8 \%$; and $72 \mathrm{~h}, 59.0 \pm 6.1 \%$ ) was interpreted as indicative of the cytoplasmic accumulation of $\mathrm{ADM}_{\text {endo }}$ while the decreased fluorescent signal suggested that HL60 constitutively secrete ADM into culture medium after synthesis, as previously reported (15).

$A D M_{\text {exo }}$ enhances the proliferation of HL60 cells. It is known that ADM is produced not only by cancer cells but also by endothelial, macrophages, and mast cells of tumor microenvironment (35), where it contributes to cancer pathogenesis both directly stimulating cancer cell growth or indirectly inducing angiogenesis and reducing the effectiveness of the immune system.

Our data (Fig. 4) show that exogenous ADM exerted a strong proliferative effect on HL60 cells, as already observed in several cell types (36-39). Indeed, after a $72 \mathrm{~h}$ incubation period, significant increases in cell number were detected in cultures treated with $\mathrm{ADM}_{\text {exo }}$ compared to resting cells. In particular, $5 \times 10^{-8} \mathrm{M}$ ADM was shown to be the most effective 

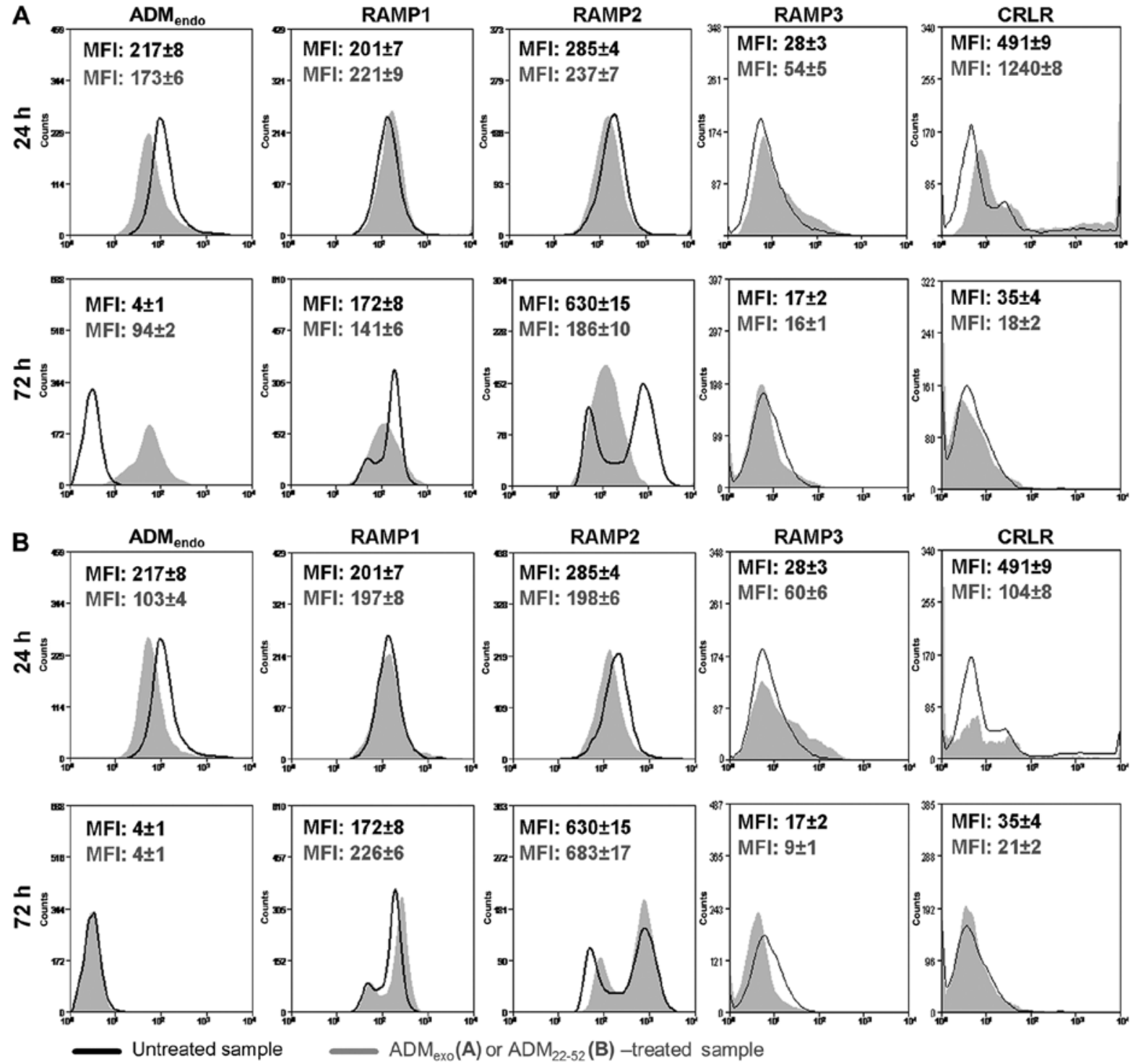

Figure 5. Expression of $\mathrm{ADM}_{\text {endo }}$, RAMP1, RAMP2, RAMP3 and CRLR in HL60 cells cultured for 24 and 72 h with $5 \times 10^{-8} \mathrm{M} \mathrm{ADM}_{\text {exo }}$ (A) or 5x10-7 $\mathrm{M}$ $\mathrm{ADM}_{22-52}$ (B) solubilized in growth medium. The positive expression of each marker was expressed as mean fluorescence intensity (MFI) \pm SD. Grey peak, samples treated with $\mathrm{ADM}_{\mathrm{exo}}$ or $\mathrm{ADM}_{22-52}$; black profile, untreated samples. The profiles are representative of three independent experiments.

concentration. In contrast, $\mathrm{ADM}_{22-52}$ demonstrated not to affect the proliferation of HL60 cells, since total cell number in primed cultures was comparable to that of untreated samples.

$A D M_{\text {exo }}$ and $A D M_{22-52}$ affect the ADM system. In the present study, we explored by FCM the modulation of adrenomedullin system ( $\mathrm{ADM}_{\text {endo }}$ and its receptors) in HL60 cells treated with exogenous $5 \times 10^{-8} \mathrm{M}$ ADM or $5 \times 10^{-7} \mathrm{M} \mathrm{ADM}_{22-52}$. When HL60 cells were in vitro cultured with $\mathrm{ADM}_{\text {exo }}$ (Fig. 5A) and $\mathrm{ADM}_{22-52}$ (Fig. 5B), a different expression profile of $\mathrm{ADM}_{\text {endo }}$ was detected in comparison to resting samples. In particular, at $24 \mathrm{~h}$, a decreased immunoreactivity for ADM was observed in primed samples suggesting that, probably due to an increased level of intracellular $\mathrm{Ca}^{2+}(40)$, a major release of endogenous ADM was promoted. At $72 \mathrm{~h}$, the secretion rate of ADM was negatively controlled by $\mathrm{ADM}_{\text {exo }}$ (Fig. 5A) but not under treatment with $\mathrm{ADM}_{22-52}$ (Fig. 5B). It is known that the expression of RAMP isoforms may change between physiological and pathological conditions (41), determining the degree of cell response to ADM. The cell sensitivity to ADM stimulation is defined both by a balanced expression of RAMPs and CRLR at cell membrane and their rapid rate of recycling. It is reported that RAMPs play pivotal roles in the transport of CRLR to plasma membrane (42). At physiological conditions, the most abundant isoform is RAMP2. Under pathological conditions, significant changes in RAMP expression levels are active under a concomitant increase in plasma ADM level (43). In the present study, the expression of AMR1 (CRLR/RAMP2), AMR2 (CRLR/RAMP3) and CGRP (CRLR/RAMP1) components was demonstrated to be altered following the treatment with exogenous ADM and $\mathrm{ADM}_{22-52}$. Indeed, at $24 \mathrm{~h}$, $\mathrm{ADM}_{\text {exo }}$ upregulated RAMP1, RAMP3 and CRLR (Fig. 5A) while $\mathrm{ADM}_{22-52}$ was effective in increasing the expression of RAMP3, but drastically reduced CRLR (Fig. 5B). In both primed groups, probably due to a receptor degradation after internalization (43), RAMP2 significantly decreased (Fig. 5), suggesting that $\mathrm{ADM}_{\text {exo }}$ and $\mathrm{ADM}_{22-52}$ mediated their activity at early phase by AMR1. These data were in accordance with 

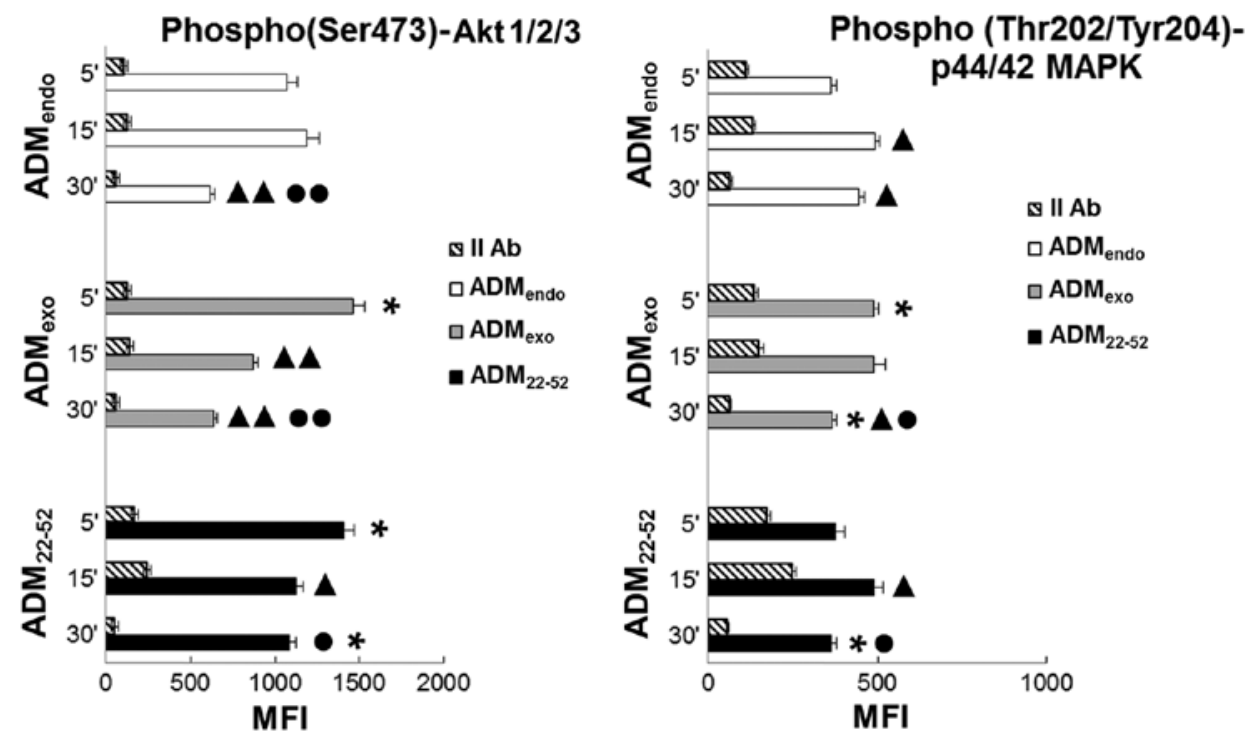

Figure 6. Changes in the activation state of Akt and MAPK upon treatment with $5 \times 10^{-8} \mathrm{M} \mathrm{ADM}_{\text {exo }}$ and $5 \times 10^{-7} \mathrm{M} \mathrm{ADM}_{22-52}$. The samples were collected at 5, 15 and $30 \mathrm{~min}$ from stimulation and analyzed by intracellular detection of phospho(Ser473)-Akt1/2/3 and phospho(Thr202/Tyr204)-p44/42 MAPK followed by flow cytometric analysis. In parallel, untreated cultures $\left(\mathrm{ADM}_{\text {endo }}\right)$ were used as reference. Hatched bars, II Ab-matched control; white bars, untreated samples $\left(\mathrm{ADM}_{\text {endo }}\right)$; grey bars, $\mathrm{ADM}_{\text {exo }}$-treated samples; black bars, $\mathrm{ADM}_{22-52}$-samples. Bars are means $\pm \mathrm{SD}(\mathrm{n}=3)$. ${ }^{*} \mathrm{P}<0.05$ vs. relative value of $A D M_{\text {endo }}$ reference group; ${ }^{\wedge} \mathrm{P}<0.05$ and ${ }^{\wedge} \mathrm{P}<0.01$ vs. relative value detected at $5 \mathrm{~min}$ in each experimental group; ${ }^{\bullet} \mathrm{P}<0.05$ and ${ }^{\bullet \bullet} \mathrm{P}<0.01$ vs. relative value detected at 15 min in each experimental group.

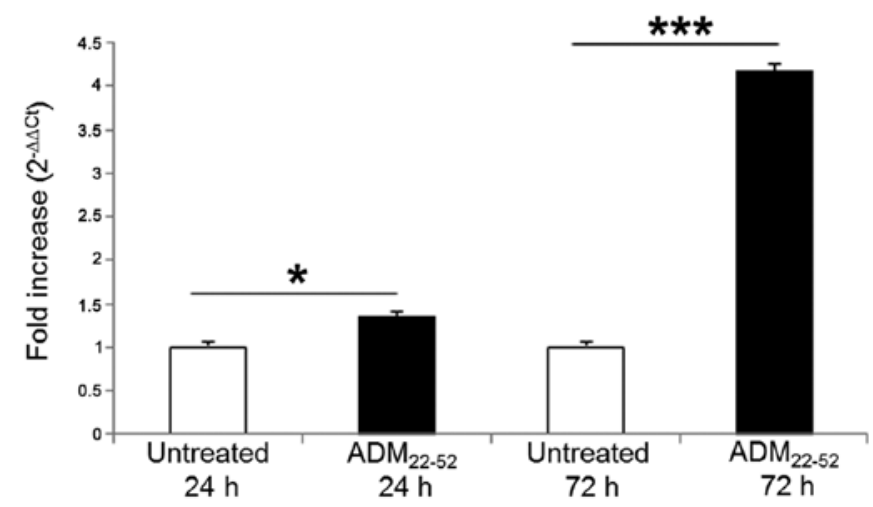

Figure 7. Quantitative RT-PCR analysis of Cul5 expression in HL60 cells treated with $5 \times 10^{-7} \mathrm{M} \mathrm{ADM}_{22-52}$ or untreated $\left(\mathrm{ADM}_{\text {endo }}\right)$ for 24 and $72 \mathrm{~h}$. In parallel, the expression of HPRT housekeeping gene was evaluated. The relative expression of Cul5 mRNA was determined using the $\Delta \Delta C T$ method. Data are reported as the fold difference calculated from the equation $2^{-\Delta \Delta C T}$ $\pm \mathrm{SD} .{ }^{*} \mathrm{P}<0.05$ and ${ }^{* * *} \mathrm{P}<0.01$ vs. $\mathrm{ADM}_{\text {endo }}$ reference group.

the hypothesis that an excess of ADM in bone marrow matrix could increase the responsiveness of leukemia cells to ADM upregulating CRLR, RAMP1 and RAMP3 (44), while the inhibition of ADM signaling could raise the cell insensitivity to stimulation by a significant reduction of ADM receptor system. At 72 h, a correlation between the increased expression level of RAMP1/2 and the release of ADM was observed in resting samples suggesting that HL60 cells could combine the release of ADM with the exposure of ADM receptors at cell membrane to control their growth. Notably, the treatment of HL60 cells with exogenous ADM reduced the release of $\mathrm{ADM}_{\text {endo }}$ and the expression of RAMP1 and RAMP2 while no change was induced by $\mathrm{ADM}_{22-52}$ compared to resting cells. The expression of RAMP3 and CRLR was drastically reduced at $72 \mathrm{~h}$ in all experimental groups. Unlike previously reported by Poyner et al (42), $\mathrm{ADM}_{22-52}$ exerted inhibitory activity of ADM signaling in leukemia cells through a negative regulation of CRLR expression, either by an increased receptor internalization followed by degradation or a block of receptor transport to plasma membrane.

$A K T$ and MAPK signaling pathways were differently modulated by $A D M_{\text {exo }}$ and $A D M_{22-52}$. Pleiotropic effects of ADM are reported to be mediated through several intracellular signal transduction pathways (43). Using HL60 leukemia cells, we explored by FCM the modulation exerted by $5 \times 10^{-8} \mathrm{M}$ $\mathrm{ADM}$ and $5 \times 10^{-7} \mathrm{M} \mathrm{ADM}_{22-52}$ on PI3K/Akt and ERK/MAPK signaling pathways, that are involved in several haematopoiesis malignancies, including AML (45-49). As shown in Fig. 6, the simultaneous detection of $\mathrm{p}(\operatorname{Ser} 473)-\mathrm{Akt} 1 / 2 / 3$ and phospho(Thr202/Tyr204)-p44/42 MAPK in resting cells $\left(\mathrm{ADM}_{\text {endo }}\right)$ suggested a constitutive activity of both pathways in HL60 cells. Hayashi and colleagues (50) reported that PI3K/Akt positively regulates the MAPK cascade, facilitating maximal ERK responses to physiological stimuli, whereas activated ERK, in turn, negatively controls the PI3K/Akt pathway. In the present study (Fig. 6), the phosphorylation level of $\mathrm{Akt}$ in $\mathrm{ADM}_{\text {endo }}$ reached the maximum value at 5 to $15 \mathrm{~min}$ and decreased at $30 \mathrm{~min}$. In parallel, the upregulation in MAPK activity from 15 to 30 min could be indicative of a reciprocal regulation loop between Akt and MAPK. Notably, the stimulation of HL60 with $\mathrm{ADM}_{\text {exo }}$ and $\mathrm{ADM}_{22-52}$ differently affected the activity of both pathways. Under stimulation with $\mathrm{ADM}_{\text {exo }}$, an increase in the expression level of $\mathrm{p}(\mathrm{Ser} 473)$-Akt and phospho(Thr202/Tyr204)-p44/42 MAPK was observed at $5 \mathrm{~min}$ indicating that HL60 cells were responsive to exogenous ADM via the PI3K/Akt and ERK/MAPK cascade. In samples treated with ADMexo compared to $\mathrm{ADM}_{\text {endo }}$ group, the activation level of MAPK unchanged from 5 to $15 \mathrm{~min}$ 


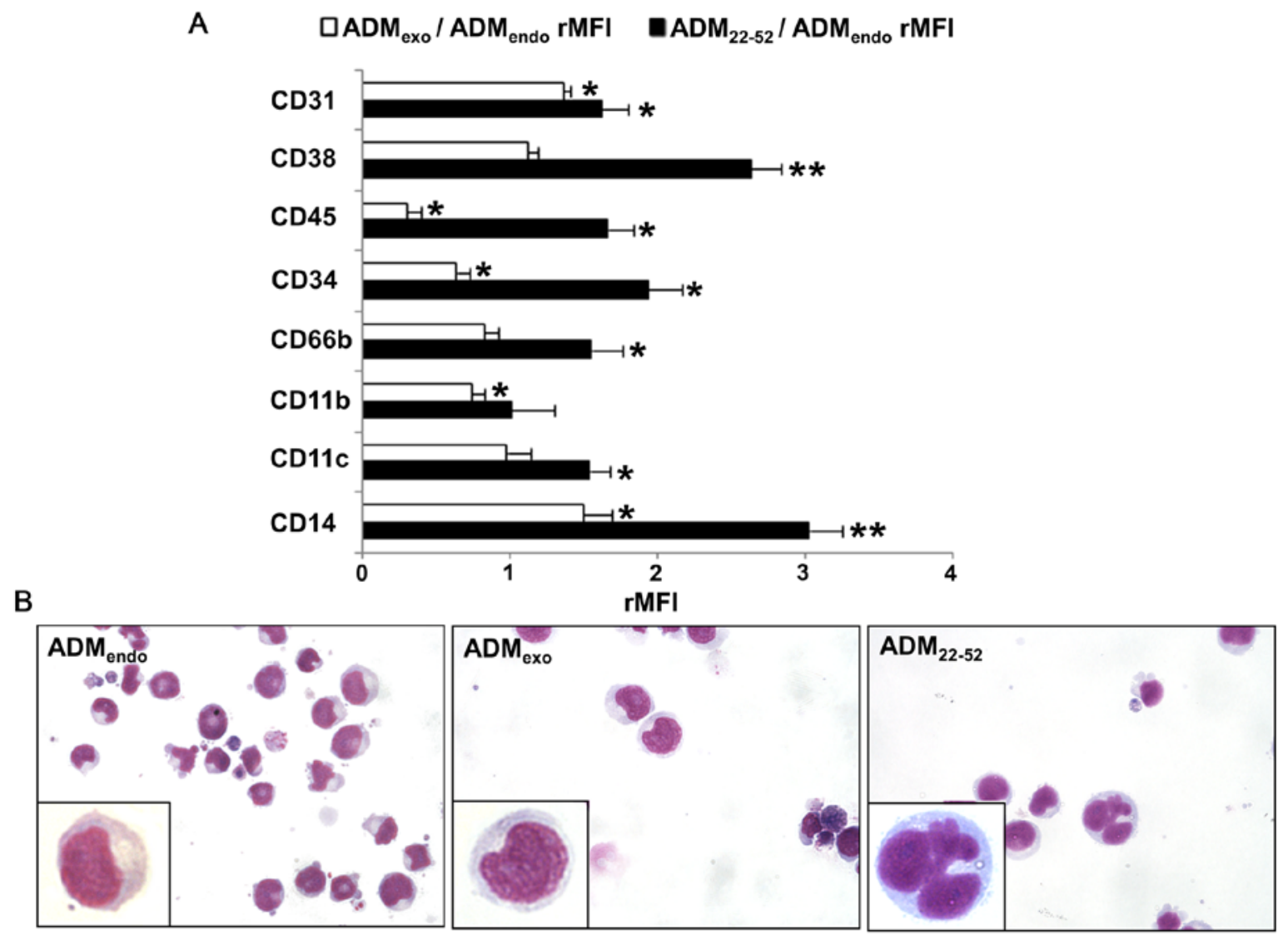

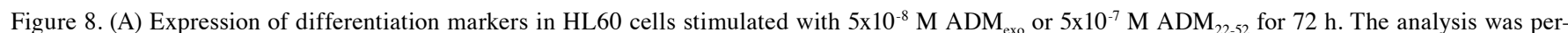
formed by flow cytometry and data are reported as the ratio of geometric mean fluorescence intensity (rMFI) obtained for samples treated with ADM exo $_{0}$ or $\mathrm{ADM}_{22-52}$ and untreated $\left(\mathrm{ADM}_{\text {endo }}\right)$ cultures. White bars, $\mathrm{ADM}_{\text {exo }} / \mathrm{ADM}_{\text {endo }} \mathrm{rMFI}$; black bars, $\mathrm{ADM}_{22-52} / \mathrm{ADM}_{\text {endo }}$ rMFI. " $\mathrm{P}<0.05$ and ${ }^{* * *} \mathrm{P}<0.01$ vs. rMFI value $\neq 1$. (B) Morphological analysis by May Grunwald-Giemsa staining of untreated $\left(\mathrm{ADM}_{\text {endo }}\right)$ and treated cells with $\mathrm{ADM}_{\text {exo }}$ or $\mathrm{ADM}_{22-52}$. Low magnification, $\mathrm{x} 400$; high magnification, $\mathrm{x} 1,000$.

while a significant decrease in phosphorylated Akt expression was observed. In contrast, the stimulation with $\mathrm{ADM}_{22-52}$ promoted the maximum activation of Akt at 5 to $30 \mathrm{~min}$ and a downregulation of MAPK activity at $30 \mathrm{~min}$. Based on this evidence, we hypothesized that the activity of $\mathrm{ADM}_{\text {exo }}$ was mainly mediated by the ERK/MAPK pathway while that of $\mathrm{ADM}_{22-52}$ was especially involved in PI3K/Akt signaling.

ADM $_{22-52}$ induces a strong differentiative induction on HL60 cells

$q P C R$. To verify the differentiative induction after the inhibition of ADM system, the expression of Cul5 was assessed by quantitative RT-PCR (Fig. 7). Cul5 belongs to the Cullins gene family, including 7 isoforms identified in mammalians. Cul5, Asb-2 (ankyrin repeat SOCS box 2), a RING finger protein (ROC/Rbx), and an adapter protein complex (elongin $\mathrm{B} / \mathrm{C}$ ) form an E3 ubiquitin ligase complex that, due to an E2 ubiquitin-conjugating enzyme, leading to the degradation of target proteins by $26 \mathrm{~S}$ proteasome (51). As component of this complex, Cul5 brings the enzyme the substrate recognition components (52). Furthermore, it seems to act as tumor suppressor in breast cancer (53) and its expression decreases in B-cell chronic lymphocytic leukemia (54). At 24 and $72 \mathrm{~h}$ after stimulation with $\mathrm{ADM}_{22-52}$, Cul5 mRNA increased 1.35- and 4.18-fold, respectively, in primed cells vs. resting cultures. Our data were in agreement with the increase of Cul5 mRNA and protein detected by Baxter et al (19) during ATRA-mediated differentiation of HL60 cells.

$F C M$. Several reports highlighted that PI3K/Akt and ERK/MAPK signaling pathways control the self-renewal and differentiation of leukemia cells. Akt was demonstrated to exert

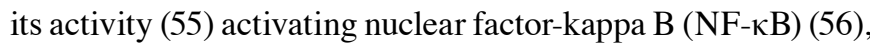
phosphorylating GSK-3 (57) and inhibiting transcription factors of FOXO family (58). Marcinkowska et al (59) demonstrated that ERK/MAPK pathway stimulates the monocytic differentiation of HL60 cells through the phosphorylation of transcription factor $\mathrm{C} / \mathrm{EBP} \beta$. As shown in Fig. 8A, the treatment with $5 \times 10^{-8} \mathrm{M} \mathrm{ADM}_{\text {exo }}$ was accompanied by an upregulation in the expression level of CD14 and CD31, which are associated with monocytic differentiation of HL60 cells $(59,60)$. Interestingly, a decreased $(\mathrm{rMFI}<1)$ or unchanged $(\mathrm{rMFI}=1)$ expression level of other markers was observed in comparison to resting samples $\left(\mathrm{ADM}_{\mathrm{endo}}\right)$, suggesting that $\mathrm{ADM}_{\text {exo }}$ could exert a negative control on the granulocytic differentiation process. In samples treated for $72 \mathrm{~h}$ with $\mathrm{ADM}_{22-52}, \mathrm{FCM}$ analysis evidenced a significant increase in the expression level of CD11b, a subunit of $\alpha \mathrm{M} \beta 2$ integrin, CD11c, an integrin $\alpha \mathrm{X}$, and CD66b, a granulocyte-specific activation antigen expressed on secondary granule membranes, that are all associated with granulocytic differentiation of HL60 cells $(21,61,62)$. Moreover, we observed the upregulation of CD45 
and CD38, that are reported to increase during myeloid maturation $(63,64)$ and ATRA-induced granulocytic/monocytic differentiation $(24,64)$. The increased MFI value of CD14 in $\mathrm{ADM}_{22-52}$ compared to that of $\mathrm{ADM}_{\text {endo }}$-samples further confirmed the granulocytic/monocytic maturation of HL60 cells (65). It is known that the expression of CD31 and CD38 on leukemic cells could exert a balanced control between extramedullary dissemination and marrow retention of leukemic cells. As previously demonstrated in ATRA-induced HL60 differentiation (66), an excess of CD38 relative to CD31 (CD31/CD38 MFI ratio<1) was detected in $\mathrm{ADM}_{22-52}$-treated cells, suggesting a higher retention of cells in bone marrow through the interaction with hyaluronate. In contrast, the excess of CD31 relative to CD38 (CD31/CD38 MFI ratio >1) in samples treated with $\mathrm{ADM}_{\text {exo }}$ evidenced an increased ability of transendothelial migration.

Histochemistry. To investigate HL60 cell differentiation, nuclear morphology of cells stained with May-GrunwaldGiemsa was performed (Fig. 8B). In $\mathrm{ADM}_{\text {exo }}$-treated cells, only ovoid and intended nuclei were detected, whereas $\mathrm{ADM}_{22-52}$ determined the appearance of differentiated cells characterized by several multilobulated segmented nuclei.

\section{Conclusions}

Understanding the aberrant expression of self-renewal pathways in myeloid malignancies is an emerging area of investigation for the development of novel treatment strategies. Extrinsic factors driven by bone marrow microenvironment are reported to regulate the growth of hematopoietic stem cells (67) within supportive osteoblastic and vascular niches (68). Among the soluble factors secreted in BM niches by stem cells (69) and stromal compartment (10), ADM synergizes with stem cell factor and Flt-3 (FMS-like tyrosine kinase-3) ligand to induce the proliferation of primitive human $\mathrm{CD}_{34}{ }^{+} \mathrm{CD} 38$-lin cells and to promote the expansion of $\mathrm{CD} 34^{+}$progenitors in culture (70). The development of hematopoietic malignancies causes a remodeling of BM microenvironment followed by the alteration of HSC function, leukemia survival, protection of cancer cells from apoptotic stimuli and development of drug-resistant phenotype (67,71). Hypoxic conditions in leukemia niche are demonstrated to support the progression of cancer and to upregulate ADM (72), thus, suggesting a correlation between the survival of leukemia cells and the increased release of ADM in tumor microenviroment (10). Consistent with the above evidence, and studies in several human tumor cell lines, including HL60 and chronic monocytic leukemia (U937) (73), our results suggest for ADM a regulatory role in the proliferation of APL by paracrine effects, as already demonstrated for ADM in modulating the activity of the hypothalamo-pituitaryadrenal axis (74), the growth of cardiac and vascular smooth muscle cells (75), the hemodynamics of brain, lungs, and kidneys (76), physiological and pathological angiogenesis (12). Using the in vitro model of HL60 cells, we demonstrated that exogenously administered ADM preserves promyelocytic leukemia cells from differentiation as shown under ADM signaling inhibition with $\mathrm{ADM}_{22-52}$ by the detection of typical differentiation features such as multilobulated segmented nuclei, Cul5 expression and increased expression level of granulocytic and monocytic antigens. As the treatment with exogenous ADM significantly stimulated the growth of HL60 cells, we speculated that paracrine ADM acts in APL niche supporting the survival of leukemia cells and promoting their transendothelial migration upregulating the cellular expression of CD31 (64). Based on the consideration that $\mathrm{ADM}_{22-52}$ stimulates both the maturation and the retention in the bone marrow of leukemia cells through an increased expression of CD38, as previously demonstrated in HL60 and human primary APL cells treated with ATRA (64), our data provide strong evidence for the therapeutical potential that the inhibition of ADM signaling could have in the treatment of APL. A potentially important therapeutic effect of the blockade of $\mathrm{ADM}_{22-52}$-sensitive receptors has been already demonstrated for endotoxic shock (77) and expansion of keratinocytes, fibroblasts (78) and adrenal cortical cells (79).

Further studies will be necessary to verify ADM expression in bone marrow microenvironment and its involvement in the induction and progression of hematopoietic malignancy.

\section{Acknowledgements}

The authors are grateful to Teresa Mariotto Pelos and Italian Leukemia-Lymphoma-Myeloma ONLUS Association, Section of Treviso (Italy) for the financial support.

\section{References}

1. Korf K, Wodrich H, Haschke A, Ocampo C, Harder L, Gieseke F, Pollmann A, Dierck K, Prall S, Staege H, et al: The PML domain of PML-RAR $\alpha$ blocks senescence to promote leukemia. Proc Natl Acad Sci USA 111: 12133-12138, 2014.

2. Nitto $T$ and Sawaki K: Molecular mechanisms of the antileukemia activities of retinoid and arsenic. J Pharmacol Sci 126: 179-185, 2014.

3. Kitamura K, Kangawa K, Kawamoto M, Ichiki Y, Nakamura S, Matsuo $\mathrm{H}$ and Eto T: Adrenomedullin: A novel hypotensive peptide isolated from human pheochromocytoma. 1993. Biochem Biophys Res Commun 425: 548-555, 2012.

4. Kitamura K, Kangawa K and Eto T: Adrenomedullin and PAMP: Discovery, structures, and cardiovascular functions. Microsc Res Tech 57: 3-13, 2002.

5. Andreis PG, Mazzocchi G, Rebuffat P and Nussdorfer GG: Effects of adrenomedullin and proadrenomedullin N-terminal 20 peptide on rat zona glomerulosa cells. Life Sci 60: 1693-1697, 1997.

6. Dickerson IM: Role of CGRP-receptor component protein (RCP) in CLR/RAMP function. Curr Protein Pept Sci 14: 407-415, 2013.

7. Shindo T, Sakurai T, Kamiyoshi A, Ichikawa-Shindo Y, Shimoyama N, Iinuma N, Arai T and Miyagawa S: Regulation of adrenomedullin and its family peptide by RAMP system: lessons from genetically engineered mice. Curr Protein Pept Sci 14: 347-357, 2013.

8. Tixier E, Leconte C, Touzani O, Roussel S, Petit E and Bernaudin M: Adrenomedullin protects neurons against oxygen glucose deprivation stress in an autocrine and paracrine manner. J Neurochem 106: 1388-1403, 2008.

9. Shichiri M and Hirata Y: Regulation of cell growth and apoptosis by adrenomedullin. Hypertens Res 26 (Suppl): S9-S14, 2003.

10. Larráyoz IM, Martínez-Herrero S, García-Sanmartín J, OchoaCallejero L and Martínez A: Adrenomedullin and tumour microenvironment. J Transl Med 12: 339, 2014.

11. Berenguer-Daizé C, Boudouresque F, Bastide C, Tounsi A, Benyahia Z, Acunzo J, Dussault N, Delfino C, Baeza N, Daniel L, et al: Adrenomedullin blockade suppresses growth of human hormone-independent prostate tumor xenograft in mice. Clin Cancer Res 19: 6138-6150, 2013. 
12. Nikitenko LL, Fox SB, Kehoe S, Rees MC and Bicknell R: Adrenomedullin and tumour angiogenesis. Br J Cancer 94: 1-7, 2006.

13. Rullé S, Ah Kioon MD, Asensio C, Mussard J, Ea HK, Boissier MC, Lioté F and Falgarone G: Adrenomedullin, a neuropeptide with immunoregulatory properties induces semi-mature tolerogenic dendritic cells. Immunology 136: 252-264, 2012.

14. Hojo Y, Ikeda U, Ohya K, Ichida M, Kario K, Takahashi M, Ikeda M, Minota S, Isumi Y, Minamino N, et al: Interaction between monocytes and vascular endothelial cells induces adrenomedullin production. Atherosclerosis 155: 381-387, 2001.

15. Kubo A, Minamino N, Isumi Y, Kangawa K, Dohi K and Matsuo H: Adrenomedullin production is correlated with differentiation in human leukemia cell lines and peripheral blood monocytes. FEBS Lett 426: 233-237, 1998.

16. Nakayama M,Takahashi K, Murakami O,Murakami H, Sasano H, Shirato K and Shibahara S: Adrenomedullin in monocytes and macrophages: Possible involvement of macrophage-derived adrenomedullin in atherogenesis. Clin Sci (Lond) 97: 247-251, 1999.

17. Del Pup L, Belloni AS, Carraro G, De Angeli S, Parnigotto PP and Nussdorfer GG: Adrenomedullin is expressed in cord blood hematopoietic cells and stimulates their clonal growth. Int J Mol Med 11: 157-160, 2003.

18. De Angeli S, Del Pup L, Febas E, Conconi MT, Tommasini M, Di Liddo R, Albertin G, Parnigotto PP and Nussdorfer GG: Adrenomedullin and endothelin-1 stimulate in vitro expansion of cord blood hematopoietic stem cells. Int J Mol Med 14: 1083-1086, 2004.

19. Baxter SS, Carlson LA, Mayer AM, Hall ML and Fay MJ: Granulocytic differentiation of HL-60 promyelocytic leukemia cells is associated with increased expression of Cul5. In Vitro Cell Dev Biol Anim 45: 264-274, 2009.

20. Ziolkowska A, Budzynska K, Trejter M, Tortorella C, Belloni AS and Malendowicz LK: Effects of adrenomedullin and its fragment 22-52 on basal and ACTH-stimulated secretion of cultured rat adrenocortical cells. Int J Mol Med 11: 613-615, 2003.

21. Livak KJ and Schmittgen TD: Analysis of relative gene expression data using real-time quantitative PCR and the 2(-Delta Delta C(T)) method. Methods 25: 402-408, 2001.

22. Paietta E, Goloubeva O, Neuberg D, Bennett JM, Gallagher R, Racevskis J, Dewald G, Wiernik PH and Tallman MS; Eastern Cooperative Oncology Group: A surrogate marker profile for PML/RAR alpha expressing acute promyelocytic leukemia and the association of immunophenotypic markers with morphologic and molecular subtypes. Cytometry B Clin Cytom 59: 1-9, 2004

23. Guglielmi C, Martelli MP, Diverio D, Fenu S, Vegna ML, CantùRajnoldi A, Biondi A, Cocito MG, Del Vecchio L, Tabilio A, et al: Immunophenotype of adult and childhood acute promyelocytic leukaemia: Correlation with morphology, type of PML gene breakpoint and clinical outcome. A cooperative Italian study on 196 cases. Br J Haematol 102: 1035-1041, 1998.

24. Taetle R, Ostergaard H, Smedsrud M and Trowbridge I: Regulation of CD45 expression in human leukemia cells. Leukemia 5: 309-314, 1991

25. Carrigan SO, Weppler AL, Issekutz AC and Stadnyk AW: Neutrophil differentiated HL-60 cells model Mac-1 (CD11b/ CD18)-independent neutrophil transepithelial migration. Immunology 115: 108-117, 2005.

26. Kim KH, Seoh JY and Cho SJ: Phenotypic and functional analysis of HL-60 cells used in opsonophagocytic-killing assay for Streptococcus pneumoniae. J Korean Med Sci 30: 145-150, 2015.

27. Veselská R, Zitterbart K, Auer J and Neradil J: Differentiation of HL-60 myeloid leukemia cells induced by all-trans retinoic acid is enhanced in combination with caffeic acid. Int J Mol Med 14: 305-310, 2004

28. Newman PJ, Berndt MC, Gorski J, White GC II, Lyman S, Paddock C and Muller WA: PECAM-1 (CD31) cloning and relation to adhesion molecules of the immunoglobulin gene superfamily. Science 247: 1219-1222, 1990

29. Brouwer RE, Hoefnagel J, Borger van Der Burg B, Jedema I, Zwinderman KH, Starrenburg IC, Kluin-Nelemans HC, Barge RM, Willemze R and Falkenburg JH: Expression of co-stimulatory and adhesion molecules and chemokine or apoptosis receptors on acute myeloid leukaemia: High CD40 and CD11a expression correlates with poor prognosis. Br J Haematol 115: 298-308, 2001.
30. Howard M, Grimaldi JC, Bazan JF, Lund FE, SantosArgumedo L, Parkhouse RM, Walseth TF and Lee HC: Formation and hydrolysis of cyclic ADP-ribose catalyzed by lymphocyte antigen CD38. Science 262: 1056-1059, 1993.

31. Muller WA, Weigl SA, Deng X and Phillips DM: PECAM-1 is required for transendothelial migration of leukocytes. J Exp Med 178: 449-460, 1993.

32. Deaglio S, Morra M, Mallone R, Ausiello CM, Prager E, Garbarino G, Dianzani U, Stockinger H and Malavasi F: Human CD38 (ADP-ribosyl cyclase) is a counter-receptor of CD31, an Ig superfamily member. J Immunol 160: 395-402, 1998.

33. Dianzani U, Funaro A, DiFranco D, Garbarino G, Bragardo M, Redoglia V, Buonfiglio D, De Monte LB, Pileri A and Malavasi F: Interaction between endothelium and $\mathrm{CD} 4{ }^{+} \mathrm{CD} 45 \mathrm{RA}^{+}$ lymphocytes. Role of the human CD38 molecule. J Immunol 153: 952-959, 1994

34. Rocchi P, Boudouresque F, Zamora AJ, Muracciole X, Lechevallier E, Martin PM and Ouafik L: Expression of adrenomedullin and peptide amidation activity in human prostate cancer and in human prostate cancer cell lines. Cancer Res 61: 1196-1206, 2001

35. Zudaire E, Martínez A, Garayoa M,Pío R, Kaur G, Woolhiser MR, Metcalfe DD, Hook WA, Siraganian RP, Guise TA, et al: Adrenomedullin is a cross-talk molecule that regulates tumor and mast cell function during human carcinogenesis. Am J Pathol 168: 280-291, 2006.

36. Miyashita K, Itoh H, Sawada N, Fukunaga Y, Sone M, Yamahara K, Yurugi T and Nakao K: Adrenomedullin promotes proliferation and migration of cultured endothelial cells. Hypertens Res 26 (Suppl): S93-S98, 2003

37. Belloni AS, Trejter M, Malendowicz LK and Nussdorfer GG: Adrenomedullin stimulates proliferation and inhibits apoptosis of immature rat thymocytes cultured in vitro. Peptides 24: 295-300, 2003

38. Iwasaki H, Eguchi S, Shichiri M, Marumo F and Hirata Y: Adrenomedullin as a novel growth-promoting factor for cultured vascular smooth muscle cells: Role of tyrosine kinase-mediated mitogen-activated protein kinase activation. Endocrinology 139: 3432-3441, 1998

39. Andreis PG, Markowska A, Champion HC, Mazzocchi G, Malendowicz LK and Nussdorfer GG: Adrenomedullin enhances cell proliferation and deoxyribonucleic acid synthesis in rat adrenal zona glomerulosa: Receptor subtype involved and signaling mechanism. Endocrinology 141: 2098-2104, 2000.

40. Ikeda U, Kanbe T, Kawahara Y, Yokoyama M and Shimada K Adrenomedullin augments inducible nitric oxide synthase expression in cytokine-stimulated cardiac myocytes. Circulation 94: 2560-2565, 1996.

41. Jacob A, Wu R and Wang P: Regulation of RAMP expression in diseases. Adv Exp Med Biol 744: 87-103, 2012

42. Poyner DR, Sexton PM, Marshall I, Smith DM, Quirion R, Born W, Muff R, Fischer JA and Foord SM: International Union of Pharmacology. XXXII. The mammalian calcitonin gene-related peptides, adrenomedullin, amylin, and calcitonin receptors. Pharmacol Rev 54: 233-246, 2002.

43. Gibbons C, Dackor R, Dunworth W, Fritz-Six K and Caron KM: Receptor activity-modifying proteins: RAMPing up adrenomedullin signaling. Mol Endocrinol 21: 783-796, 2007.

44. McLatchie LM, Fraser NJ, Main MJ, Wise A, Brown J, Thompson N, Solari R, Lee MG and Foord SM: RAMPs regulate the transport and ligand specificity of the calcitonin-receptorlike receptor. Nature 393: 333-339, 1998.

45. Steelman LS, Pohnert SC, Shelton JG, Franklin RA, Bertrand FE and McCubrey JA: JAK/STAT, Raf/MEK/ERK, PI3K/Akt and BCR-ABL in cell cycle progression and leukemogenesis. Leukemia 18: 189-218, 2004.

46. Brognard J, Clark AS, Ni Y and Dennis PA: Akt/protein kinase $\mathrm{B}$ is constitutively active in non-small cell lung cancer cells and promotes cellular survival and resistance to chemotherapy and radiation. Cancer Res 61: 3986-3997, 2001.

47. Hsu J, Shi Y, Krajewski S, Renner S, Fisher M, Reed JC, Franke TF and Lichtenstein A: The AKT kinase is activated in multiple myeloma tumor cells. Blood 98: 2853-2855, 2001.

48. Nicholson KM and Anderson NG: The protein kinase B/ Akt signalling pathway in human malignancy. Cell Signal 14: 381-395, 2002

49. Nakatani K, Thompson DA, Barthel A, Sakaue H, Liu W, Weigel RJ and Roth RA: Up-regulation of Akt3 in estrogen receptor-deficient breast cancers and androgen-independent prostate cancer lines. J Biol Chem 274: 21528-21532, 1999. 
50. Hayashi H, Tsuchiya Y, Nakayama K, Satoh T and Nishida E: Down-regulation of the PI3-kinase/Akt pathway by ERK MAP kinase in growth factor signaling. Genes Cells 13: 941-947, 2008.

51. Kohroki J, Nishiyama T, Nakamura T and Masuho Y: ASB proteins interact with Cullin5 and Rbx2 to form E3 ubiquitin ligase complexes. FEBS Lett 579: 6796-6802, 2005.

52. Kile BT, Schulman BA, Alexander WS, Nicola NA, Martin HM and Hilton DJ: The SOCS box: A tale of destruction and degradation. Trends Biochem Sci 27: 235-241, 2002.

53. Fay MJ, Longo KA, Karathanasis GA, Shope DM, Mandernach CJ, Leong JR, Hicks A, Pherson K and Husain A: Analysis of CUL-5 expression in breast epithelial cells, breast cancer cell lines, normal tissues and tumor tissues. Mol Cancer 2: $40,2003$.

54. Kalla C, Scheuermann MO, Kube I, Schlotter M, Mertens D, Döhner H, Stilgenbauer S and Lichter P: Analysis of 11q22-q23 deletion target genes in B-cell chronic lymphocytic leukaemia: Evidence for a pathogenic role of NPAT, CUL5, and PPP2R1B Eur J Cancer 43: 1328-1335, 2007.

55. Abdullah M and Seman Z: Role of signaling pathways in acute myeloid leukemia. In: Myeloid Leukemia-Basic Mechanisms of Leukemogenesis. Koschmieder S and Krug U (eds). InTech, Rijeka, pp429-448, 2011

56. Ozes ON, Mayo LD, Gustin JA, Pfeffer SR, Pfeffer LM and Donner DB: NF-kappaB activation by tumour necrosis factor requires the Akt serine-threonine kinase. Nature 401: 82-85, 1999.

57. Fukumoto S, Hsieh CM, Maemura K, Layne MD, Yet SF, Lee KH, Matsui T, Rosenzweig A, Taylor WG, Rubin JS, et al: Akt participation in the Wnt signaling pathway through Dishevelled. J Biol Chem 276: 17479-17483, 2001.

58. Sykes SM, Lane SW, Bullinger L, Kalaitzidis D, Yusuf R, Saez B, Ferraro F, Mercier F, Singh H, Brumme KM, et al: AKT/FOXO signaling enforces reversible differentiation blockade in myeloid leukemias. Cell 146: 697-708, 2011.

59. Marcinkowska E, Garay E, Gocek E, Chrobak A, Wang X and Studzinski GP: Regulation of C/EBPbeta isoforms by MAPK pathways in HL60 cells induced to differentiate by 1,25-dihydroxyvitamin D3. Exp Cell Res 312: 2054-2065, 2006.

60. Trayner ID, Bustorff T, Etches AE, Mufti GJ, Foss Y and Farzaneh F: Changes in antigen expression on differentiating HL60 cells treated with dimethylsulphoxide, all-trans retinoic acid, alpha1,25-dihydroxyvitamin $\mathrm{D}_{3}$ or $12-O$-tetradecanoyl phorbol-13-acetate. Leuk Res 22: 537-547, 1998.

61. Bellón T,López-Rodríguez C, Rubio MA, Jochems G, Bernabeu C and Corbi AL: Regulated expression of p150,95 (CD11c/CD18; $\alpha \mathrm{X} / \beta 2)$ and VLA-4 (CD49d/CD29; $\alpha 4 / \beta 1)$ integrins during myeloid cell differentiation. Eur J Immunol 24: 41-47, 1994.

62. Park DJ, Chumakov AM, Vuong PT, Chih DY, Gombart AF, Miller WH Jr and Koeffler HP: CCAAT/enhancer binding protein epsilon is a potential retinoid target gene in acute promyelocytic leukemia treatment. J Clin Invest 103: 1399-1408, 1999.

63. van Lochem EG, van der Velden VH, Wind HK, te Marvelde JG, Westerdaal NA and van Dongen JJ: Immunophenotypic differentiation patterns of normal hematopoiesis in human bone marrow: Reference patterns for age-related changes and disease-induced shifts. Cytometry B Clin Cytom 60: 1-13, 2004.

64. Lewandowski D, Linassier C, Iochmann S, Degenne M, Domenech J, Colombat $\mathrm{P}$, Binet $\mathrm{C}$ and Hérault $\mathrm{O}$ : Phosphatidylinositol 3-kinases are involved in the all-trans retinoic acid-induced upregulation of CD38 antigen on human haematopoietic cells. Br J Haematol 118: 535-544, 2002.
65. Hansen PB, Kjaersgaard E, Johnsen HE, Gram J, Pedersen M, Nikolajsen $K$ and Hansen NE: Different membrane expression of CD11b and CD14 on blood neutrophils following in vivo administration of myeloid growth factors. Br J Haematol 85 : 50-56, 1993.

66. Gallay N, Anani L, Lopez A, Colombat P, Binet C, Domenech J, Weksler BB, Malavasi $\mathrm{F}$ and Herault O: The role of platelet/ endothelial cell adhesion molecule 1 (CD31) and CD38 antigens in marrow microenvironmental retention of acute myelogenous leukemia cells. Cancer Res 67: 8624-8632, 2007.

67. Lemischka IR: Microenvironmental regulation of hematopoietic stem cells. Stem Cells 15 (Suppl 1): 63-68, 1997.

68. Chiarini F, Lonetti A, Evangelisti C, Buontempo F, Orsini E, Evangelisti C, Cappellini A, Neri LM, McCubrey JA and Martelli AM: Advances in understanding the acute lymphoblastic leukemia bone marrow microenvironment: From biology to therapeutic targeting. Biochim Biophys Acta ppi: S01674889(15)00293-1, 2015. doi: 10.1016/j.bbamcr.2015.08.015

69. Bakondi B, Shimada IS, Perry A, Munoz JR, Ylostalo J, Howard AB, Gregory CA and Spees JL: CD133 identifies a human bone marrow stem/progenitor cell sub-population with a repertoire of secreted factors that protect against stroke. Mol Ther 17: 1938-1947, 2009.

70. Chute JP, Muramoto GG, Dressman HK, Wolfe G, Chao NJ and Lin S: Molecular profile and partial functional analysis of novel endothelial cell-derived growth factors that regulate hematopoiesis. Stem Cells 24: 1315-1327, 2006.

71. Williams CA and Lavik EB: Engineering the CNS stem cell microenvironment. Regen Med 4: 865-877, 2009.

72. Kocemba KA, van Andel H, de Haan-Kramer A, Mahtouk K, Versteeg R, Kersten MJ, Spaargaren M and Pals ST: The hypoxia target adrenomedullin is aberrantly expressed in multiple myeloma and promotes angiogenesis. Leukemia 27: 1729-1737, 2013.

73. Takahashi K, Morimoto R, Hirose T, Satoh F and Totsune K: Adrenomedullin 2/intermedin in the hypothalamo-pituitaryadrenal axis. J Mol Neurosci 43: 182-192, 2011.

74. Tsuruda T, Kato J, Kitamura K, Kuwasako K, Imamura T, Koiwaya Y, Tsuji T, Kangawa K and Eto T: Adrenomedullin: A possible autocrine or paracrine inhibitor of hypertrophy of cardiomyocytes. Hypertension 31: 505-510, 1998.

75. Shichiri M, Fukai N, Ozawa N, Iwasaki H and Hirata Y: Adrenomedullin is an autocrine/paracrine growth factor for rat vascular smooth muscle cells. Regul Pept 112: 167-173, 2003.

76. Lah JJ and Frishman WH: Adrenomedullin: A vasoactive and natriuretic peptide with therapeutic potential. Heart Dis 2: 259-265, 2000.

77. Mazzocchi G, Albertin G and Nussdorfer GG: Adrenomedullin (ADM), acting through $\mathrm{ADM}(22-52)$-sensitive receptors, is involved in the endotoxin-induced hypotension in rats. Life Sci 66: 1445-1450, 2000.

78. Albertin G, Carraro G, Parnigotto PP, Conconi MT, Ziolkowska A, Malendowicz LK and Nussdorfer GG: Human skin keratinocytes and fibroblasts express adrenomedullin and its receptors, and adrenomedullin enhances their growth in vitro by stimulating proliferation and inhibiting apoptosis. Int J Mol Med 11: 635-639, 2003.

79. Rebuffat P, Macchi C, Malendowicz LK and Nussdorfer GG: Up-regulation of adrenomedullin gene expression in the regenerating rat adrenal cortex. Int J Mol Med 20: 551-555, 2007. 